\title{
The Universalisation of American Capitalism
}

\author{
Raluca Bejan, University of Toronto
}

Tariq Ali, The Extreme Centre: A Warning (London: Verso Books, 2015). 200 pp. $\$ 19.95$ Paperback.

Vivek Chibber, Postcolonial Theory and the Specter of Capital (London, Verso Books, 2013). 306 pp. $\$ 31.50$ Paperback.

Vijay Prashad, The Poorer Nations: A Possible History of the Global South (London, Verso Books, 2014). 304 pp. \$21.95 Paperback.

Without a crisscrossing common premise and quite distinctive in content, format, and length, the aforementioned works share joint ideas on the theme of globalised capitalism. Tariq Ali and Vijay Prashad insist on the dominance of American capital, and respectively on the transition from American liberalism to American neoliberalism, although Ali takes a journalistic approach and Prashad provides a historical account on the matter. Chibber gets tangentially connected with the two, though his theoretically framed message stands on a parallel road from the factual ones of his colleagues.

An indirect defense of Marxism, Chibber's text criticizes the field of subaltern studies and connects with Tariq Ali in contesting certain presuppositions and assumptions with regards to European dominance and Eurocentrism, while tackling the universalisation of capital within our transnational, global era. It joins Prashad in addressing the North-South political dynamics and argues that models of rationality and modernization were used in the South to partially escape the Northern subservience. Prashad further shows how such rationality was economically coopted by neoliberalism.

This essay engages with the content thematically rather than analyzing the books on an individual basis, simultaneously reflecting on their common and divergent argumentative points.

\section{Capital and Its Universalisation}

The ideological culture of global capitalism, Tariq Ali argues, raises profits by removing institutional obstacles, citizens, countries and progressive tax reforms, and by claiming a fake congruence between corporate interests and working class needs. Chibber demonstrates that capital's universalisation is a routine phenomenon within the twentieth century, diversely occurring all around the globe and without neces- 
sarily disturbing local cultures, a thesis contested by the field of post-colonial and subaltern studies, which argued for the peculiar aspect of capitalism in the East.

Subalternists' argument, as outlined by Chibber, claims that capital's universalisation developed from within the context of Europe's bourgeois revolutions, in 1640 in England and 1789 in France, where the dominance of capitalist classes relied on peasantry and workers' consent. Feudalism was overthrown, secularism and socialism were subsequently established, and a national market and community were created in virtue of liberal principles of rights, liberties, and equality. In South Asia, the subalternists argue-India in particular, as per Partha Chatterjee's claimthe bourgeoisie was unable to destroy the ancient regime. In fact, it accommodated feudal classes and older forms of pre-modern politics, hence creating capitalism without a capitalist culture and without capitalist power relations. In contrast with England and France, where domination integrated the dominated working classes into the political project of the nation, the Indian bourgeoisie did not speak for the nation and used coercion to relate to the landed classes, hence exercising dominance and not hegemony, i.e. Ranajit Guha's argument, whereas hegemony is defined via dominance on consent and not through coercion. Without hegemony, the Indian bourgeoisie remained cemented within a pre-bourgeois consciousness - i.e. Dipesh Chakrabarty's argument - around communal, ethnic and religious ties, and abandoned capitalism's universalising drive. The dominant axis of politics was overlaid on community and ethnicity and not on class based bourgeois rationality.

In India, the argument continues, capital relied on interpersonal forms of domination-Chakrabarty exemplifies with the working relations in Calcutta jute mills, where a Scottish manager would act much more coercively than he would ever act at home - and not on typical European forms of impersonal and institutional coercion (123). Marxist and liberal theories are only valid in settings with a secure bourgeois culture and inadequate for understanding Indian, Eastern realities, which had different historical trajectories. Postcolonial theoretical categories need to encompass the fragmented particularities of the East and to be positioned against totalizing and homogenizing European concepts.

Chakrabarty criticises Marxist analyses because they incorporate local particularities within a universalised history of capital, indifferent of local differences, hence socio-political situations are deemed to be the same in Detroit as in Bombay, for example (221). Chakrabarty distinguishes between History 1, whereas local institutions and structures contribute to capitalist reproduction, once capitalism gets established in a former non-capitalist region, and History 2, whereas not all practices assist capitalism's reproduction; some remain independent and disrupt the universalisation of capital. Capitalism globalised every corner of the world, however, this alone does not imply its universalisation in terms of producing similar political and cultural transformations in the East and the West.

Chibber contra-attacks the subalternists claim(s) to fundamental difference for being grounded on faulty understandings of the British and French revolutions 
as bourgeois events (Chapter 3). The English Revolution, Chibber argues, was not anti-feudal. It happened after the transition to capitalism; hence it was more about what type of capitalism England should have. Its bourgeois oligarchy was indifferent to subaltern interests and only accommodated them when necessary; for example, lower orders were excluded from politics; the electoral arena was dominated by the Whig and Tory oligarchies; trade unions did not get legal protection until 1871; demands of Levellers and Quakers were ignored. Similarly, in France, while The Third Estate aimed to dismantle the absolutist state and to change it into a constitutional monarchy, there was no commitment to the rights of subaltern groups. Mass demands were oftentimes marginalised; for example, electoral rights were withheld until mid-century; the right to strike was not granted until 1864; that of establishing trade unions not until mid 1880s, and that of free and universal education not until 1802. The Third Estate was neither revolutionary nor capitalist. Out of the 610 representatives only 90 had ties with commerce. They represented what we would call today the salaried middle class, employees or independent producers, only claiming larger rights for themselves. Subaltern classes, the peasantry in particular, forced their concerns by way of revolt. The revolution had finally become anti-feudal and democratic yet not because of a "bourgeois project" but because peasants forced in their involvement.

In the classic understanding, the European events were pivotal in the development of capitalism and liberalism, however, for Chibber, such a causal link is weak; their main contribution was the strengthening of state-building and nationbuilding identities. In fact, both the Indian bourgeoisie and the European elites aimed to minimise the power of subaltern demands and push out the labouring classes, hence reaching hegemony without consent. The European experience, thus, is not a benchmark for hegemonic success.

Chibber argues that the power relations in Chakrabarty's capitalist jute mills were congruent with other coercive forms of capitalist production, regardless of these being colonial or not. What capitalism universalises, Chibber states, is a strategy of economic reproduction. Irrespective of geographical location, managers directly or indirectly extend control over workers. The same arbitrary managerial practices are used in England, US and Bengal, for example. To maximise profit, employers extract the maximum labour from employees, thus the real goal of production is the exchange-value - the abstract labour, relationally rewarded via comparison with other labourers - and not necessarily the concrete value. To extract work, capitalists also oppose collective organising and take advantage of inherent cultural or ethnic divisions within labour.

Abstract labour appears in concrete identities, as in concrete labourers, however, since the labour market-site is one of generalised insecurity, no one is guaranteed employment. People rely on familial and social networks, hence racial and ethnic community ties became tools for cementing material security. These preconstructed divisions lead to capital's accumulation via identitary difference, an ar- 
gument also referred to by Marx, that capitalists promote racial differentiation, for example, in having used Irish workers as a way of weakening the trade unions in England.

Chibber argues (224-246) that for as long as History 1 established itself and gets reproduced over time, we can infer its universalisation. Even if History 2 modifies capital's reproduction, it does not change its basic rules of replication. Both histories can coexist in parallel, without antagonism, particularly as raced and gendered political processes are easily absorbed within the cycles of capitalist accumulation. Corrosive conditions that lead to capital's destabilisation, entrepreneurism and plunge the economy into crisis, can also exist within History 1, as shown by major theoreticians of capitalism, Smith and Keynes. Similar to what Prashad writes in relation to Marx and Engels' prediction, of capitalism breaking away from its European roots, and globalising, while maintaining older forms of repression.

Capital's universalising tendency is supported by what Tariq Ali calls the extreme centre, a mainstreaming of politics whereas all parliamentary parties, from centre-right to centre-left preserve the dominance of capital. The extremes are not at the ends of the political spectrum, but rather within its centre, sustaining the market in a fundamentalist way. This "symbiosis of big money and minimalist politics" (42), has become "a model for the new-style democracies" (148). Prashad also refers to the neoliberalism with southern characteristics, showing the extreme-centre tendencies within the South as another example of the universalisation of capital.

According to Chibber, it is irrelevant that Marxist and post-enlightment theories are Eurocentric, since the East and the West share a global history, where the universalisation of capital follows, more or less, a similar logic. Theories originating in Europe can also be applied to the East and postcolonial understandings of capitalism, politics, history, and agency should be questioned. The subalternist predicament, that the Global South cannot be interpreted via Western concepts of historical materialism, is also destabilised by Prashad's references to the neoliberalism with Southern traits (Chapter 2).

\section{The Americanisation of Capital}

Capitalist supremacy is driven by Washington, Ali argues. Existent disputes with China, Russia, and the servile EU are unable to challenge the technological, geographical and ideological US imperial domination, strongly sustained by the cultural principles of wealth accumulation, worship of money, and private property (77). The US started its hegemonic trajectory in 1971, Prashad states (25) when, unable to pay its creditors, it delinked the dollar from the gold standard. This enabled the US to print currency and run deficits, a move followed by UK and other European nations. Currencies floating one against another led to short-term instability and to investors turning to commodities to protect against inflation, which raised the prices of gold and oil. Countries were now holding the US dollar as a tool for wealth, and with the dollar standard substituting the gold one, Washington could manoeuvre 
the world.

The US uses NATO to preserve its global hegemony and to keep its European allies at bay, writes Ali (110). NATO was initially set up in 1949 to block Soviet aggression against the West. During the Cold War, NATO was mainly a propaganda tool to control allies rather than to fight enemies. After the Cold War, it continued to keep European powers under American influence and to transform the former Soviet Bloc countries into compliant US satellites. Four dozen military interventions were conducted by NATO after the Cold War, a much higher number in comparison with the sixteen NATO operations that took place during the Cold War years. In 2010, the US had 662 bases overseas in Central Europe, Middle East, Asia Pacific, Caribbean, East/West Africa and 88 on US territories. Following the tensions in Yugoslavia, NATO bombed Serbia; it intervened in Afghanistan by arming the Mujahideen radicals with Saudi and Pakistani help, and carried out bombardments in Libya in 1981 and 1986; it deployed troops in Sinai; it sustained the Israeli invasion of Lebanon; it backed the reactionary Hindu Kush who aimed to destabilise the Marxist government in Kabul; and supported South Africa's apartheid regime. Prashad also mentions (Chapter 2) the violence within Central America, where the US joined reactionary forces to supress revolutionary movements. The US used Honduras as a base for arming right-wing paramilitaries; it invaded Grenada in 1983, and Panama in 1989 (131). The US labeled Cuba, Iran, Iraq, Libya, and North Korea as "rogue" states, countries outside the international system whose aim is to destroy the system. Jacques Derrida, however, has later inverted the "rogue" label back on the US, in his 'Essays on Reason' (Derrida 2005).

Masked under so-called progressive ideas of "third way," "conflict-free politics," and "beyond left and right," European politics are nowadays Atlanticised and the British polity is subservient to the US. Yet, US hegemony is in continuous decline, Ali argues (76). The richest global country cannot care, feed, or employ its poor, mainly African Americans and Hispanics. One in seven Americans, twenty five percent of children and twenty percent of elderly are living below the poverty line. In 1998, under Bill Clinton, the wages of the bottom 80 percent were lower than in 1989, and much lower than 1979. US workers labour ten to twenty percent more hours than Western Europeans, and even more than the Japanese. Spending on wars and national security, seven trillion dollars since 2001, as documented by Prashad (19), was accompanied by cuts to social services and tax breaks for the rich. Prashad and Ali agree that although US has a weakened economic status, it still dominates ideologically and militarily, hence we will not see its collapse anytime soon.

With the victory of Hayek and the Chicago school, neoliberalism succeeded when the whole world accepted the Washington consensus (Ali 56). This paved the way for privatizations at home and wars abroad. Ali exemplifies with the privatization of the Nationalized Health Services (NHS) in the UK, previously one of the most socialised health care systems. The 2010 Health and Social Care Act, 
he argues, is now modelled after the American system. Universal health care was abolished, hence people were forced to resort to private health insurance. Ali presents an interview with Allyson Pollock, Professor of Public Health at Queen Mary University London, who argues that the NHS privatisation is reflective of the US style neoliberal politics (35-36). The US exhausted its own funds within the health care industry, running at eighteen percent of GDP, where a nine to ten percent GDP in Europe has led health care investors to look for new markets. Prashad argues that Hayek's ideological triumph also allowed the G7 to consolidate their power and to take advantage of colonial contexts, insisting that the South should export its way out of crisis. In 1987, the South sent 30 billion in debt payments to the North. This undermines David Harvey's idea, that neoliberalism started in New York and got imported via IMF to the rest of the world, Prashad argues (151). In fact, neoliberalism triumphed incipiently in the Global South, sustained by the ideological commitment of the elites in Africa, Asia and Latin America.

In 1970, the US exploited its downturn crisis to restore profitability. The government assaulted its own economy, Prashad writes (58), in the hope that destruction would create something anew. Credit was severely tightened, interest rates rose as high as twenty-one percent by 1980, the old manufacturing sector collapsed, and Americans could no longer keep their standards of living. In the beginning of Reagan's administration, there was a systematic attack on labour and trade unions. When Reagan later introduced Keynesianism, the new asset bubbles created by credit card and real estate debt increased Wall Street's power over the state and society. Low interest rates in the North allowed financial institutions to inflate credit and consumption. They enabled large sums to travel the globe in search for investment opportunities, which increased Brazil, India, and South Africa's ability to export services. But, these reforms had differential effects: the rich benefitted much more at the expense of the poor; growth did not just come from industries such as information technology, but also from cannibalistic economic activity, including privatization and real estate speculation. The growth rate expanded the middle class but it increased inequality between classes and within regions: high urban unemployment among working class, high rates of farming suicides in India and destruction of labour unions and labour protections. Weakened labour led to the development of the informal sector in these countries, which deepened social divisions. In 2000, William Easterly, the Senior Adviser in the Macroeconomic Division at World Bank said that countries who borrowed from IMF and World Bank would be worst off. IMF and World Bank knew that people wanted social goods yet they continued to champion growth as the only way for development, Prashad states (207).

When the US raised interest rates, this had a catastrophic effect on the Third World, Prashad continues (60). In 1973, the Global South states had a debt of 130 billion, which rose to 612 billion by 1982. The South wanted an International Debt Commission yet the North refused to see their debt as political. Real farmers 
in the US and Europe were replaced with factory farming. Subsidies to the Atlantic agriculture gave the North advantages in the global food market. And via Free Trade agreements such as NAFTA in 1994, the North eliminated producers from Mexico, India, Ghana, and Bangladesh. Migrations followed, as impoverished rural workers from the South, especially women, joined factories to create products for the Atlantic shops.

Sensing the widening disparity between the North and the South, since according to the World Bank 700 million people lived in absolute poverty in 1979, and aiming to counter the political risks of rebellion, the Brandt report was published in 1980, to address such issues, by the Independent Commission. The idea was to extend Keynesianist principles into the international arena and to transfer wealth to the South, which will be used to buy goods from the North, to bring the Northern economy back to life (75). To transfer the wealth, aid levels would be increased and a World Development Fund would be set up through progressive taxes on Gross National Products, on international trade, on military expenditure and mining. The money would be released without conditions. The Brandt report, framed on the idea of "mutual interests," was the main statement of American liberalism focused on the well-being of the global poor, Prashad argues, although it did not directly acknowledge the role of power per se.

The Brandt report was well received by social democrats both in the North and the South. The G7 met to discuss it. Reagan did not want to attend, but Thatcher urged him to. In October 1981 in Cancun, twenty-two states attended the International meeting for Cooperation and Development. Cuba was not allowed to participate. The USSR stayed out on the premise that Global South problems are the result of colonialism, hence it is the West alone that needs to answer to its history. Reagan brought forward a neoliberal agenda, arguing that poverty cannot be transcended overnight; that the road to prosperity is only via economic freedom and individual incentives; that the US program of free trade should aid the private sector and not the government; and that free trade and liberalised financial systems and not wealth transfers should be the engines for development. The Brandt team was defeated. It later met in Kuwait in 1982 to debrief Cancun and came out with a book that received little attention_Common Crisis North-South: Cooperation for World Recovery. The Cancun summit, Prashad writes (87), finished the Atlantic liberalism and moved the agenda to neoliberalism.

By 1987, the debt in the South was sitting at 47 percent of the gross national products. Chandra Hardy's papers at the World Bank, on the Mexican and African debts, argued for debt cancelation or at least debt restructuring on concessional terms, for instance lengthening the repayment period and revisiting the payments on a yearly basis, so countries should not have to cut away their basic livelihoods. However, Hardy's position was not fully endorsed by the South, as Prashad shows (Chapter 2). Manmohan Singh, for example, the General Secretary for the South Commission, did not advocate for debt cancelation, rather for con- 
verting it into securities and trading it at a discounted rate. This way the banks would get some of their money back and the South would move towards a growth agenda.

Washington's neoliberal logic continued in a similar manner during the recent 2008 economic crisis. Credit-induced consumerism combined with real estate and financial speculation produced the jobless growth that crashed in 2007. The US absorbed billions of dollars from the Global South to cover its current deficit. The poor financed the rich, Prashad states. The US and the EU bailed the falling banks, Ali also argues (101) and people had to pay for a deregulated banking system and for dismantling of the social welfare state. The housing bubble was supported by Wall Street, Ali continues, which encouraged people to take on second mortgages and higher personal debts. When the bubble collapsed, the banks were the ones rescued. The EU imposed austerity favouring the German, French, and British banking systems, further collapsing the countries of Ireland, Greece, and Iceland, while keeping Spain, Portugal and Italy in precarity. The responsibility for the crisis was placed on Southern Europe, although no one drew attention to the high deregulation of high finance, writes Prashad. The US introduced Keynesianism to stimulate its economy, however, in Europe, the solution became about punishing the poorest states, according to Ali (57-58). In Greece, for example, youth unemployment is very high and wages are down by 50 percent. In Spain, single pensions and salaries are sustaining entire households, with unemployment at 26 percent and casual labour paid at two to three euros per hour. Italy is in recession, with 42 percent of Italians unemployed. In Portugal, family businesses, which have for long supported the economy, have vanished, and those without work cannot even access unemployment benefits. In Ireland the best and the brightest have left. The European Troika, composed of European Commission, the European Central Bank and IMF now governs Portugal, Ireland, Cyprus and Greece.

At the time of the Greek financial collapse, the idea was to cut government spending and tax the working class and the precariat without touching the consumption of the elites, says Prashad (244-246). Merkel promoted austerity. Obama, a light version of Keynesianism. Yet Obama had in mind the US economy, on the premise that an anticipated collapse of the European banks will threaten the US banking system and a Grexit would trigger similar issues in Italy and Spain, countries in which US banks were much more leveraged. Obama's Keynesianism had little to do with social good and more with creating a firewall for protecting banks, argues Prashad.

Atlantic dominance is also visible in relation to international property rights. Atlantic transnational firms hold the patent over the most advanced technologies needed for economic growth. Much of the Northern growth was built by controlling intellectual property, says Prashad (Chapter 2). Jobless growth and debtfuelled consumerism relies on rents paid on intellectual property, including brands and designs, subsequently locking the South out of scientific and technological developments. 
To maintain its dominance, the US has always tried to shut down international dissent. For example, when Japan, suspicions of World Bank's protection of EU and US interests, supported the creation of the Asian Development Bank (ADB), Washington spoke against it, demanding conditions of privatisation and free market principles for giving out loans. When the AIDS epidemic reached catastrophic levels in Africa, Asia and Latin America in the 1990s, and South Africa passed the Medicines Amendment Act to allow imports of cheaper medicine from India, under the former Indian Patent Act, which protected the process and not the product, firms could sell AIDS drugs at a fraction of the prices advertised by the Northern companies. The US pressured South Africa to revoke its law, threatening to reduce aid to the country and placing it on the Special 301 watch list; it was later removed from the list due to pressures from the AIDS movement.

Americanism has become the only feasible internationalism. Without the Soviet Bloc, Francis Fukuyama's prediction, that inequalities will not disappear and dramatic social transformations, such as socialism, would no longer occur, came true. America was sold as the planet's future, with its free trade agreements and open borders for business. The North acted its imperial dominance by having its wishes multiplied, while the South's pleas were just "sometimes added, [and] mainly subtracted" (Prashad, 26).

\section{The Left as the Extreme Centre and Neoliberalism with Southern Characteristics}

It is the internationalism of the New Labour that subordinated British polity to the US, Ali states (44). Labour is nowadays a party of war and finance. Under Tony Blair the gaps between executive salaries and average wages have become the largest in Europe. Between 1990-1996, a million people lost their homes through repossession by mortgage companies, and in 2009 alone, one million properties were in negative equity. The flexible labour market encouraged individualism and consumerism, normalised unemployment, and rationed disability and housing benefits to means-tested payments and incentives to work.

New Labour additionally gave full authority to the Bank of England to determine monetary policy and detached it from government control; it cut welfare benefits for single mothers, and it charged tuition fees to all university students, measure opposed by the former Conservative government. Despite protests, university fees were raised in 2004 and 2010, on the premise that those benefiting from higher education should fund it. When the former conservative government privatized the railways, the Labour, once in power, pledged for public-private partnerships on transport, although 65-85 percent of the public opinion was in favour of renationalising the railways.

Ali gives a financial account of New Labour party members (Chapter 1). Tony Blair, the former Prime Minister has a fortune estimated at 40-60 million. He owns two limited liability companies: Firerush Ventures and Windrush Ventures. 
Alan Milburn, former Health Secretary and a former radical leftist, is nowadays the Director of Covidien, a global multibillion health care company and an Adviser for Lloyd's Pharmacy Healthcare, Pepsico and the private equity firm Bridgepoint. Charles Clarke, former Education Secretary and Home Secretary also worked as a KPMG consultant. Hilary Armstrong, former Secretary of State was the Chairperson of the waste company SITA. Stephen Byers, once part of the far left is now the Chairman of the water treatment company ACWA and Ritz Climate Offset Company. Richard Caborn, former Sports Minister, works as a Consultant to AMEC (nuclear industry) and the Fitness Industry Association. Frank Field, former Welfare Reform Minister is the Director of Medicash. These are only some of the many aforesaid examples. The Labour Party followed the same steps as the Tories, which is why Ali talks about the extreme centre as having the same ideological line from right to the left.

With the transition to American neoliberalism, extreme centre tendencies have also became visible in the South, Prashad demonstrates (Chapter 2). Global South countries wanted acceptance within the First World and integration within capitalist structures. Julius Nyerere, the former chairman for the South Commission, initially pushed for an agenda of freedom and equality, eradication of poverty, a minimum standard of living, a ceiling on wealth for individuals and nations and a resources transfer from the rich to the poor. Nyerere aimed to promote a strategy of solidarity in the South and to seek unity as an instrument of liberation and not of domination. The Commission's work was divided: some favoured a people centered development, around a strategy of basic needs, and some wanted growth-led development, as in modeling the Atlantic North. Yet a people-centered development would have had to include women, Indigenous people, slum dwellers, and such an approach was not ultimately endorsed by the Commission. These groups raised issues of deprivation and environmental collapse, however the actions of Indigenous people faced as much resistance in the South as they did in the North, for example, displacement was common in the case of Barabaig people under Nyerere's regime. Overall the South Commission did not actually see (Indigenous) 'people' as essential to their new project. The rhetoric of people-centred development, in terms of the language of basic needs, production for domestic consumption, common planning and development of regional solidarity links, was hijacked by the neoliberal agenda of deregulation and good governance.

In the 1990s, the final report of the South Commission argued for the transition from an agrarian economy to an industrial one. The document prioritised growth as a solution to the Third World problems. The idea was to imitate the new industrialised countries of the Pacific Rim: South Korea, Taiwan and China, the only ones showing some success in terms of their GDP, which is why the Commission put forward Third World multinationals, such as Samsung and Hyundai. China became the main locomotive of the South. Benefiting from the Maoist fruits, including a generation of healthy, literate and able people (Prashad 226), China was 
able to move from an agricultural state devastated by the Japanese occupation to an industrialised country rivalling the North.

The simultaneous invasion of Kuwait by Sadam Hussein, which coincided with the release of the Commission's final report in Caracas, drifted the public attention away from the South. The G7 states said the report does not have a clear commitment to the market, the only guarantee for a successful economy. In Havana, Fidel rejected the report, particularly on the premise that it posed the market as the most natural institution for resource distribution. The neoliberalism with Southern characteristics has started. Not as a capitulation to the North but as a new approach, as Prashad shows.

By the early 2000s, the research analysts at Goldman Sachs started to pay attention to the new Southern alliance comprised of Brazil, Russia, India and China (BRICS). These states had very large populations and were major producers of goods and services. Brazil and Russia supplied raw materials to India and China, who then supplied manufactured goods and services to the North. Yet the Southern locomotives had little political power and they could not push issues of debt transfer onto the agenda. BRICS did not really challenge the Northern dominance. Unable to stand against the US and NATO military power and unable to create a new institutional an ideological alternative to neoliberalism (another example of the universalisation of capital), BRICS mainly looked for entry into the institutions controlled by the North and started to advocate for democracy at IMF, World Bank and the UN. They did manage however, to be partially integrated into the decisionmaking. In 2003, France invited the Plus5 countries (Brazil, China, India, Mexico and South Africa) to the G8 Evian summit. At the next two summits, G8 leaders spoke of institutionalising a dialogue with the South's locomotives. Angela Merkel wanted the G8 and the Plus5 to create the conditions for global economic stability.

In pushing reforms to please the North-Atlantic markets, the South leaders did not talk about neoliberalism but about modernisation. Brazil, India and South Africa pressed for policies with three main orientations: to please the bond market by cleaning fiscal and monetary policy, as in to cut deficits, re-evaluate currency within the dollar regime, and privatize state run enterprises; to please the multinational corporations and to accede to the new intellectual property regimes; and to discipline workers, as in veering away funds from social welfare to individualised training. From 2008 onwards, the locomotives of the South were ironically expected, says Prashad, to drag the North out of its debt crisis.

\section{Culture and Ideology Substituting Capitalism and Class}

Despite the universalisation of capital, discussions largely rest, nowadays, in critiquing culture and ideology, particularly vis-à-vis the ideas of Eurocentrism, nationalism, colonialism and economic determinism, trends especially supported by the post-colonial field of studies. As Chibber shows, subalternists such as Chatterjee and Chakrabarty claim that agents in the East have a different psychology and dif- 
ferent peasant consciousness than agents in the West. Conceptions of individual rights, rationality and self-interest are predominant in the West while in the East those of duty, obligation, honour, religiosity and community, prevail. It is why Enlightment theories of class are inadequate to explain peasants' political agency.

Yet thinking that the East is solely an other-orientated culture, lacking notions of individuality and material self-interest, has deep Orientalist inclinations, Chibber argues. For instance, in the case of Muslim peasants' agitations against the traditional Hindu landlords — named zamindars in Bengali-the wealthy jotedars, also Muslim, mobilised general peasant demands by appealing to material interests. The jotedars possessed wealth, resources and connections, which made them an asset to the anti-zamindar movement. Peasants did not join forces with the jotedars because they were Muslim, but because they had interdependent material reasons and because it was in their interest to do so. Rationality and individual interest were also part of peasant consciousness. Indian peasantry looked just like peasantry anywhere in Europe, China or the Middle East. The cultural essentialism of Subaltern studies, Chibber continues, which conceptualises peasants as unable to recognize their situation as oppressive, diminishes in fact, subaltern agency. Material interests are universal at root and anchored in universal desires. Leaving one's village to find employment in Calcutta or Paris is motivated by the desire to earn more. When workers migrate, the need for shelter and work are not peculiarities of a specific, let us say Indian, culture. It is rather a matter of people following their individual interests.

Although structural and cultural reasons coincide, conceptualizing rationality outside culture implies that cultural dispositions exist a priori and choices are just internalised habits. Yet actors do not just make choices according to cultural norms but also according to material interests. Indian subaltern classes are motivated towards well-being as much as their Western counterparts. Subalternists' fascination with religion and Indigeneity is particularly Orientalist, because it contains the conservative belief in Western singularity. Thinking that something exists in the West that psychologically determines labouring classes to pursue bourgeois liberties and basic human rights, autonomy, democracy, and this something lacks in the East, is exactly what sustains the idea of Western uniqueness, of the genius of Western civilization onto which imperialism was founded. Subsuming reason as the sole appendage of the West constructs the East once again as exoticised and essentialised, Chibber concludes.

\section{Alternative Politics}

Many global protests erupted during the 1990s. Against neoliberalism, against the dominance of international finance, against the rise in petroleum prices, government backed austerity, increased unemployment, against global hunger and against highest rates of inequality: in Venezuela around Caracas (1989), Los Angeles (1992), Madrid (1994), Seattle (1999), Washington (2000), Genoa (2001), Gothenburg (2001), 
Barcelona (2002). According to Prashad, these prompted messages for a fairer distribution of resources, for autonomy from private capital, social justice and the right to well-being. Recently, Ali states, two political moments have challenged the capitalist crisis (Chapter 5). First, in 2011, the Arab spring confronted the Western backed governments, however it ended up exchanging one form of domination for another. Second, the general strikes and protests within Southern Europe, for instance in Greece, Spain, aimed to create a new social order inside capitalism and to challenge Troika's extreme centre position.

Although much has happened since Ali's book was written, at the time, in 2015, Syriza, Podemos, and the radical Independence campaign in Scotland created indeed the hope for radicalised politics. By now, however, Syriza failed in Pasok's steps. Constituted as mass fractions, initially modeled after Hugo Chavez's party, Ali continues, Syriza and Podemos tried to imitate South American politics, as in so far only South America provided political and economical resistance to the US imperialism and conducted anti-capitalist structural reforms: against IMF, privatisation and social restructuring. The Latin America Pink Tide, which included working class and Indigenous campaigns against neoliberalism, comprised the most revolutionary movements in the South. Once Chavez took control over the Venezuelan government, many South American nations elected leftist governments: Brazil (2002), Argentina (2003), Uruguay (2004), Bolivia (2006), Chile (2006), Ecuador (2006), Paraguay (2008) and Peru (2011). Yet a divide developed between two lefts, Prashad states: the modern and reformist one (Argentina, Brazil, Chile) coming out of the traditional left of the past; and the second left (Venezuela, Bolivia, Ecuador) born out of the Latin American populism and nationalism, which equated the modern left with neoliberalism (Prashad Chapter 4).

In Ali's eyes, Scotland represents another example of political self-determination (51) aiming to create a Scotland with proper health services, free education, and social housing. The 2014 independence referendum had the highest level of voter registration since the introduction of universal surfage. Britain always treated Scotland the same way Europe treated Syriza and the New Labour reduced the Scottish Parliament to the power of a local council. Ali predicts that within few years there will be a high demand for another referendum, as polls show that $52 \%$ would vote for separation (48).

Prashad adds to the topic by historicising decades of anti-colonial struggles within the South (Chapter 1). In 1961 the Non-Aligned Movement (NAM) was formed on principles of egalitarism. It advocated for peace and justice, hoping to reconstruct the social landscape co-opted by IMF, World Bank and the Atlantic powers. A central component in its organisation was the UN Conference on Trade and Development (UNCTAD) in 1964, which included Africa, Asia, Latin America, the Socialist Bloc, Yugoslavia, and some Scandinavian countries. UNCTAD was under attack by the North. In Belgrade in 1983, UNCTAD VI provided a clear analysis of the problems of the South, however it could not put forward a new 
agenda or a new policy direction. It rather reiterated the demands from UNCTAD V from Manila (1979) and UNCTAD IV from Nairobi (1976). The creation of BRICS in 2003, although it embraced the neoliberalism with Southern characteristics, it still challenged the orthodoxy of the Global North, Prashad states. These states' hostility towards the US grew from 2002 onwards, when the US began its war in Iraq. Brazil, India and South Africa issued statements condemning the war as illegitimate. When BRICS met in 2012 in New Delhi, they critiqued the world economic order and proposed new policy guidelines. The BRICS states also created a new credit facility in local currencies to reduce the cost of trade transactions between them. The creation of a new development bank, South Banco Sur (a practical institutional foundation outside neoliberalism), was additionally explored.

Prashad writes about the development of the World Social Forum (WSF) as a new example of internationalism opposing the IMF structural reforms. Mainly comprised of activists, white-collar workers, students, public employees, WSF embodied a similar pattern from Indignados to Occupy. It met in Mumabi (2004), Karachi (2006), Nairobi (2007), Belem (2009) and Dakar (2011). The Dakar forum unfolded over three principled axes: critical analysis of capitalism; resistance against capitalism, imperialism and oppression; and the development of popular alternatives. Some have argued that the forum has now become an annual festival with no impact. Others, however, have claimed that its ideological strength rests exactly within its non-hierarchical organization. Yet WSF centred on internal processes (i.e. who gets to speak and when) and proved itself incapable of creating a robust internationalism. It later fragmented into regional and continental units (i.e. Asia Social Forum, US Social Forum, etc).

\section{Academic Complicity}

Current philosophers are unable to interpret the world, Ali states (61). Although economists have for long argued that speculation should be made illegal and the focus on finance should be majorly reduced, academics have turned their backs onto redistributive policies and have showed a break with social democracy. From Chibber, we can imply that such trend seems particularly connected with the development of post-colonial studies. Subalternists stood out initially because they incorporated their radical critique within post-Marxism. Nowadays, according to Chibber, the postcolonial field lacks coherence and systematicity and is mainly sustained by young fashionable academics, backed up by a plethora of journals, chairs and self-styled radical departments, whose aim is mainly career advancement.

Post-colonial theory is attractive within academia because of its hostility to Eurocentrism. Yet Chibber shows that the subaltern field fails to displace Eurocentrism; it resurrects it, and promotes a hidden Eurocentrism by following the conceptual antithesis of the West as the sole site of reason and East as that of traditionalism. Although many critical scholars have rejected such revived Orientalism, it is very common in North American academia, where these notions have been 
empirically and theoretically defended.

\section{Conclusion}

The books are a pleasant read. Engaging, definitely aligned with current political events, yet very dense. Ali's text comes with a little bit of a delay, given the tumultuous changes within Europe during the last couple of years. Not as radical as it was preconized, Syriza ended up as the proponent of the political and economical status quo, particularly when it accepted EU's austerity package despite the fact that in July 2015 the Greeks voted against the Troika Memorandum. The party itself got divided, and a smaller radical fraction, Popular Unity, was created from within. The Brexit vote followed a year later, bringing into play ideas of culture and ideology, themselves related to preserving the ideal of Britishness as a community of value, although the vote was also prompted by austerity measures targeting the working class. Ali's book might be a little bit past its time, especially as his speculative predictions about Syriza became a political disappointment. Nothing in this political formation materialised congruently with the radical Pink Tide experienced in the South.

Ali's text also reads as less of an analysis and more as a description of the status-quo. Its structure and format are slightly disjointed. Ali writes about the extreme centre, without clearly defining it from the get-go. He then jumps to enumerate former labour ministers' involvement within the private realm, then to write about the NHS privatisation. He brushes over many things without fully developing them.

Prashad is extremely factual and articulate. He dissects and serves on a plate the North American dominance, and his analyses are particularly pertinent within the context of Donald Trump's administration and the latest US official attack on Syria. Written up as following an archival investigation, which Prashad started with the South Commission's archives in Geneva, the text is filled with an avalanche of date-based and location-based facts, making it difficult at times to draw the line between historical, factual enumerations and actual analyses. Prashad also jumps back and forward in time and provides sometimes less significant details regarding who wrote what to whom, when, and under what circumstances, again making it difficult to follow the "plot." Prashad's text brings much needed documentation on the death of American liberalism and the birth of neoliberalism, contextualising its up-and-coming approach in the South. He concludes by proposing three working principles for a twenty-first century Commission: universal access to basic needs; economic power, as in controlling multinationals and veering away from "money" as the medium to command economic activity; and a social wage and better public goods.

Chibber's text is theoretically complex. The connection with Ali and Prashad rests in the way he approaches the notion of capital and its universalisation, however, Chibber's arguments are also an important step in creating a thorough, 
much-needed critique of the fields of subaltern and post-colonial studies. His work can be adjacently extrapolated to analyses of institutional diversity which, from corporate hiring practices to diversifying entry numbers at Harvard University, tend to take up the whole conversational topic within North American academic circles. Discussions about the commodification of difference and diversity are important, especially now that diversity efforts are commodified and culturally tradable on a new market that capitalism extended to.

Chibber's strongest claim, that the subalternist discourse is Orientalist in essence, and that it misinterprets the universalisation of capital, lays strong grounds for a primary critique of the field of post-colonial studies. His argument, however, could come across as negating the South's subaltern positioning. Critiques of subaltern studies still need to directly and openly acknowledge the inferior positioning to which the South was subjected. More so, Chibber oftentimes conflates the field of subaltern with that of the post-colonial, although his text merely addresses subaltern arguments, and does not thoroughly engage with a broader post-colonial discourse. Generalising this critique to the entire field of post-colonial studies is a stretch. Oddly, Chibber makes no reference to Gayatri Chakravorty Spivak's work, Can the Subaltern Speak, nor does he engage with staple figures from the post-colonial field, for example Edward Said, to draw the generalised claims he aims towards. Chibber's analyses oftentimes read as if they were conducted at the level of semantics, containing ad litteram interpretations and mot-à-mot critiques. The reader is bestowed with carefully approaching the text to capture all of its minuscule nuances, task experienced as repetitive at times. Chibber oftentimes contrasts and compares ad litteram every sentence of his opponents' arguments; as in X endorses Y's view, although Y's view is shaped by $\mathrm{M}$ and $\mathrm{X}$ also disputes $\mathrm{B}$, although $\mathrm{Y}$ agreed with $\mathrm{B}$, and so on. When Chibber insists on destabilising the rules within History 1 it does not further develop how capitalism found new ways of reproducing itself, following its destabilising crises. For instance, after the 2008 downturn, the financial sectors were strengthened and capitalism was further readapted.

An indirect aspect resulting from the three works comes from demystifying our understandings of Europe. Ali shows how the US dominates Europe and the UK; Prashad demonstrates how Southern Europe is treated much like the Global South; and Chibber shows that subalterness is not confined to local geographies. Deconstructing the standing of the European revolutions as the comparison benchmark for subaltern understandings of Indian bourgeoisie, ads to our theoretical queries vis-à-vis considerations of homogenised Eurocentrism. One cannot just easily infer claims of a de facto homogenised European dominance and Eurocentrism as it was the case in the immediate post-colonial times. Many parts of Europe are colonized by capital, and the colonising nation is nowadays the US, whose dominance is more pungent than ever. It is perhaps time we shift gears from criticising Eurocentrism and placing the gaze onto Americancentrism. 


\section{REFERENCES}

Derrida, Jacques. Rogues: Two Essays on Reason. Standford: Stanford University Press, 2005. 